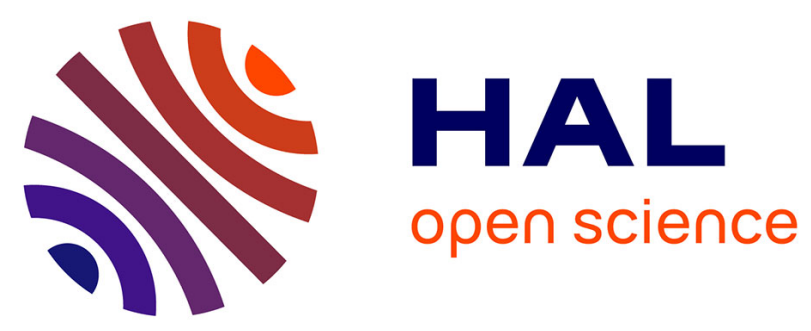

\title{
Traumatic events and early maladaptive schemas (EMS): Prison guard psychological vulnerability
}

\author{
A.H. Boudoukha, N. Przygodzki-Lionet, M. Hautekeete
}

\section{To cite this version:}

A.H. Boudoukha, N. Przygodzki-Lionet, M. Hautekeete. Traumatic events and early maladaptive schemas (EMS): Prison guard psychological vulnerability. European Review of Applied Psychology / Revue Européenne de Psychologie Appliquée, 2016, 66 (4), pp.181 - 187. 10.1016/j.erap.2011.05.004 . halshs-01911879

\section{HAL Id: halshs-01911879 \\ https://shs.hal.science/halshs-01911879}

Submitted on 12 Nov 2018

HAL is a multi-disciplinary open access archive for the deposit and dissemination of scientific research documents, whether they are published or not. The documents may come from teaching and research institutions in France or abroad, or from public or private research centers.
L'archive ouverte pluridisciplinaire HAL, est destinée au dépôt et à la diffusion de documents scientifiques de niveau recherche, publiés ou non, émanant des établissements d'enseignement et de recherche français ou étrangers, des laboratoires publics ou privés. 
Original article

\title{
Traumatic events and early maladaptive schemas (EMS): Prison guard psychological vulnerability
}

\section{Événements traumatogènes et schémas précoces inadaptés (SPI): vulnérabilités psychiques des surveillants de prison}

\author{
A.H. Boudoukha ${ }^{a, *}$, N. Przygodzki-Lionet ${ }^{\mathrm{b}}$, M. Hautekeete $^{\mathrm{b}}$ \\ a EA 3259, laboratoire "Éducation, cognition et developpement " chemin de la Censive-du-Tertre, BP 811227, Nantes cedex 3, France \\ b Université Lille 3 Charles-de-Gaulle, rue du Barreau, BP 60149, 59653 Villeneuve d'Ascq cedex, France
}

\section{A R T I C L E I N F O}

\section{Article history:}

Received 5 October 2008

Accepted 21 May 2011

\section{Keywords:}

PTSD

ASD

Early maladaptive schemas (EMS)

Prison

Inmate

\begin{abstract}
A B S T R A C T
Introduction and objective. - Guards are employed to maintain prison security partly because of inmate violence. In this environment, traumatic events such as attacks are frequent. In the aftermath of such events, two major psychopathological consequences can affect guards: (a) post-traumatic stress symptoms (PTSS) or disorder (PTSD or ASD) and (b) early maladaptive schema (EMS) re-enactment. The current study addresses inmate-on-staff attacks in terms of post-traumatic stress symptoms (PTSS) and EMS re-enactment.

Method and results. - Two hundred and thirty-five prison guards were assessed for (1) PTSS with the Impact of Event Scale-Revised, and (2) EMS with SCP II, a French EMS inventory. Post-traumatic stress symptoms are high among prison guards and "mistrust" EMS are significantly more re-enacted than other EMS. Correctional guards with PTSD show significantly higher EMS re-enactment levels than those without post-traumatic stress symptoms.

Conclusions. - It appeared that inmate-on-staff attacks cause re-enactment of "mistrust" EMS in particular. We hypothesize a particular relationship between EMS and PTSD: after a traumatic event, EMS may be reenacted. Once EMS are re-enacted, they act as a risk factor for post-traumatic stress symptoms. In return, post-traumatic symptoms may maintain EMS enactment. Further studies are necessary; nevertheless, we now know the importance of psychological help for prison guards.
\end{abstract}

(C) 2011 Elsevier Masson SAS. All rights reserved.

\section{R É S U M É}

Les surveillants sont employés en prison pour maintenir la sécurité en raison de la violence des personnes incarcérées. Les agressions sont donc des événements traumatogènes fréquents qui peuvent provoquer deux conséquences psychopathologiques majeures : (a) des symptômes de stress post-traumatiques (TSP ou TSA) et (b) une réactivation des schémas précoces inadaptés (SPI). La présente recherche s'intéresse à l'effet des agressions vécues par les surveillants en termes de stress post-traumatiques et de réactivation des SPI. Notre population est composée de 235 surveillants de prison. Nous avons évalué (1) les symptômes post-traumatiques à l'aide de la version française révisée de l'échelle d'impact des événements (IES-R) et (2) l'activation des SPI par le biais du SCP II, une échelle française de mesure des SPI. Les résultats montrent que les surveillants rapportent des niveaux de stress post-traumatique élevé et qu'un SPI, le SPI « méfiance », est plus activé que tous les autres. Les surveillants qui présentent un niveau diagnostique de TSPT rapportent des niveaux d'activation de SPI plus intenses comparés à leurs homologues sans trouble de stress traumatique. La prison renforce l'activation de SPI comme la «méfiance». Nous posons l'hypothèse d'une association spécifique entre SPI et stress post-traumatique: on peut observer une réactivation des SPI à la suite d'un événement traumatogène. Une fois les SPI réactivés, ils vont agir comme

\footnotetext{
* Corresponding author.

E-mail address: Abdel-Halim.boudoukha@univ-nantes.fr (A.H. Boudoukha).
} 
facteur de risque devant la symptomatologie post-traumatique (TSP ou TSA). En retour, le stress posttraumatique pourrait maintenir l'activation des SCPI. Ces hypothèses méritent des études plus poussées, dans l'avenir. Pour le présent, il faut améliorer et développer les prises en charge psychologiques proposés aux professionnels travaillant en prison.

(c) 2011 Elsevier Masson SAS. Tous droits réservés.

\section{Introduction}

\subsection{Prison and post-traumatic stress symptoms}

Prison is a dangerous setting (Przygodzki-Lionet and Noël, 2004). Prison staff and inmate safety and security are primary goals in the administration of correctional facilities. Whilst prison disorder and violence such as escapes, riots, etc. have significantly decreased, mental disorders and suicide rates among inmates are increasing (Duburcq et al., 2006; Magaletta et al., 2008) and the rate of inmate-on-staff assaults has increased in French prisons (DAP, 2009).

Consequently, correctional facility guards are chronically confronted with violence, as well as inmates' mental disorders and suffering (Sorensen et al., 2011). These situations meet the core features of the traumatic events or trauma defined in the ICD-10 (OMS, 1994): "stressful event or situation of an exceptionally threatening or catastrophic nature, which is likely to cause pervasive distress in almost anyone".

The experience of such an event, during which "the person's response involved intense fear, helplessness, or horror"(APA, 2004), often leads to post-traumatic stress symptoms. Typical symptoms include (a) re-experiencing symptoms: episodes of repeated reliving of the trauma (intrusive memories, dreams, etc.); (b) numbing/avoidance symptoms: a sense of "numbness" and emotional blunting, detachment from other people, anhedonia and avoidance of activities and situations reminiscent of the trauma and (c) hyper-arousal symptoms: unresponsiveness to surroundings. DSM-IV-TR distinguishes between acute and chronic PTSD (APA, 2003). Acute PTSD is diagnosed if the duration of symptoms is less than 3 months and onset is greater than one month post-trauma. Chronic PTSD is diagnosed if the duration of symptoms is three months or more.

Moreover, patients frequently expressed a pervasive change in themselves and their world after experiencing the trauma. Their conceptualization of the world as reasonably controllable and predictable and their conceptualization of the self as reasonably protected are shattered by the traumatic event they experienced (Janoff-Bulman, 2004). After trauma, the victim's world becomes a meaningless, uncontrollable, and unpredictable place in which her/his self is vulnerable to random malevolence (Dalgleish, 2004)

\subsection{Schemas and PTSD}

The schema-based models for PTSD specifically account for these sufferer's psychological changes following a trauma (Young et al., 2005).

The term schema is used to refer to a way of mentally representing knowledge. Its task is the organization of knowledge at different levels of abstraction (Rummelhart, 1975). Schemas bestow order to the innumerable life experiences through their coding and their representation in the mind (Brewer and Nakamura, 1984; Neisser, 1976). Schemas are mental representations that serve as models of aspects of the world, the self and others (Rusinek, 2006). Consequently, "the existence of schemas obviates the need to mentally reinvent the wheel with each new experience by providing a blueprint against which that experience can be fitted" (Dalgleish, 2004).

PTSD is an interesting disorder that enables understanding of how experiencing a traumatic event can change the sufferers' view of themselves, of others and of the world. Janoff-Bulman (1992) argued that "to the extent that particular assumptions [i.e. schemas] are held with extreme confidence and have not been challenged, they are more likely to be utterly shattered, with devastating results for the victim". Schema-based theories highlight two major explanatory principles in PTSD psychopathology:

New information or experiences that are significantly inconsistent with schemas are disruptive. Schemas must either assimilate or organize them in some way and/or become changed by them. The organizational-functional schema model explains how schema organization is compelled to modify itself because of its method of functioning and the way schemas develop (Hautekeete, 1998). This explains individual differences in the content and nature of schemas as a function of past experience. It also highlights the pathological or healthy direction of the process.

The current and past sense of reality is organized in a schemaconsistent way. The selection and the interpretation of events in a schema-consistent manner reinforce pre-existing schemas.

These processes can become maladaptive when there is a systematic bias: a dysfunctional schema will produce a disabling effect on the psychological processing (Cason et al., 2002; Hautekeete et al., 2006). EMS theory addresses that phenomenon.

\subsection{EMS and the re-enactment process}

The schema-focused approach postulates that people are unconsciously drawn to events, situations and relationships that trigger their EMS (Young and Klosko, 1993). An EMS is defined as an extremely stable and enduring interpersonal theme that develops during childhood, is elaborated throughout one's lifetime, and is dysfunctional to a significant degree.

The purpose of an EMS is to replicate childhood experiences (notably 'toxic' ones) in an attempt to put things right on a psychological level by producing a different outcome from the one experienced in childhood. The mechanism of "re-enactment" can be seen as a psychological "self-healing process", which aims to heal the underlying EMS (Young et al., 2005). When an EMS becomes rigid and extreme, the individual goes on perpetually re-enacting the schema. EMS have been extensively studied in adults but the results concerning the number of EMS vary, from study to study, from 15 EMS (Schmidt et al., 1995) to 13 EMS (Hautekeete et al., 2001).

What is the relationship between PTSD, EMS and prison guards? The re-enactment of an EMS in the work context is a significant factor in the causation and maintenance of mental disorder and work-related dysfunctions (Bamber and McMahon, 2008). These "re-enactments" are particularly manifested in the interpersonal domain, where the individual relates to others in the here and now as if they were actually back in the problematic relationship from the past. Prison is a work setting that lends prison guards and inmates readily to this, since the analogies between the early family environment and prison situations are numerous. 
In conclusion, there is a growing body of evidence supporting the links between EMS, PTSD and the re-enactment hypothesis. However, it has been subject to little empirical investigation.

\subsection{Aims and hypotheses}

This study aimed to fill gap in the literature by providing empirical data, which would highlight the link between traumatic events, post-traumatic symptoms and EMS re-enactment using a population of prison guards. Specifically, it was hypothesized on the basis of the reviewed existing literature and previous research findings that:

- EMS will be differentially re-enacted among prison guards, reflecting specific relationships to inmates;

- a prison guard's EMS re-enactment will vary according to posttraumatic stress symptoms: the more severe the post-traumatic symptoms are, the higher the EMS re-enactment will be.

\section{Study design and method}

\subsection{Participants}

The participants in the study were 235 prison guards in French correctional facilities. There were 46 women and 188 men, ranging from 22 to 56 years old, with a mean age of 36 years and 11 months old ( $\sigma=7$ years and 5 months). Average tenure was 11,5 years ( $\sigma=7.4$ years), varying from 2 months to 30 years. Most of our prison guards had graduated from high school: $48 \%$ with a high school diploma, $43.5 \%$ with a bachelor's degree and $8.5 \%$ a master's degree. Such rates are representative of prison guards, according to the French correctional department statistics department (DAP, 2010).

Victimizations among our prison guards were very common: more than $87 \%$ had experienced an attack of some sort, whether verbal, physical or with a weapon; more than $88 \%$ had been confronted with another type of traumatic event (i.e., attempted inmate suicide, inmate self-mutilation, etc.).

\subsection{Measurements used}

A small battery of questionnaires consisting of a range of selfreport measurements was devised. In order to potentially increase response rates and reduce the demands made upon participants, consideration was given to questionnaire length, completion time and readability. It was estimated that it would take approximately 30 min to fully complete the entire set. Questionnaires used in the present study are presented hereafter.

\section{Participant information sheet and demographics questionnaire}

The participant information sheet outlined the purpose of the study, how to take part in the study and contact details for the researcher. The demographics questionnaire was used to collect participant information such as age, gender, tenure, occupation and specialty, and experiences of traumatic events therapy. Most items were multiple-choice questions, with the exception of the item "other traumatic events", which was open-ended in nature.

\section{Impact of Event Scale Revised (IES-R)}

Post-traumatic stress symptoms were assessed by using the 22item IES-R French version (Brunet et al., 2003). The IES-R is a short, easily administered self-report questionnaire. Each item is rated on
Table 1

Number of subjects according to the IV post-traumatic stress "Diagnosis Level".

\begin{tabular}{lc}
\hline Diagnosis Level & Number of Subjects \\
\hline No symptoms & 118 \\
ASD & 47 \\
PTSD & 63 \\
\hline
\end{tabular}

a five-point scale ranging from 0 ("not at all") to four ("extremely"), reflecting the extent to which the particular symptom was a problem for the respondent during the past week. The scale includes eight items for intrusion symptoms, eight items for avoidance and numbing symptoms, and six items for hyperarousal symptoms. The IES-R is now a commonly used post-traumatic stress symptom evaluating instrument in trauma-related research and clinical settings (L. Wang et al., 2011). Reliability and validity of the French version have been well-documented (Brunet et al., 1998; Brunet et al., 2003; Vaiva et al., 2003).

The authors consider that a total score of post-traumatic stress between 22 and 36 would characterize an Acute Stress Disorder (ASD). A higher score would be the expression of a Post-Traumatic Stress Disorder (PTSD). Through this coding we have created an independent variable named "Post-Traumatic Stress Diagnostic Level $^{1}$ " (DL) which comprises three degrees: No Symptoms, ASD and PTSD (Table 1).

\section{Early Maladaptive Schemas Questionnaire (SCP II)}

SCP II is a French EMS assessment questionnaire (Hautekeete et al., 2001). The SCP II is a self-report measure consisting of 65 items that identify the presence of 13 EMS (Table 1). There are five items tapping into each of the 13 EMS. Each item is rated on a sixpoint Likert scale, and the EMS score is the mean score of the items included therein. The scores for each EMS range from 1 to 6 .

Young et al. (2005) suggest that, if used clinically, items with scores of five or six are considered as being of clinical interest. See Table 2 for a presentation of the signification of each EMS of the SCP II.

\subsection{Procedure}

The written agreements of the National Department of the Correctional allow us to access prison facilities. Research took place in prisons chosen according to the type of establishment. Files containing our study questionnaires were proposed to the correctional staff employed in these various prisons. In accordance with the CNIL recommendations (French IT and Freedom commission), we asked the subjects to duly return the files anonymously to a relay person from the university not directly concerned with research, whose address is given on the last page of the file.

A total of 430 sets of questionnaires were returned, which is the equivalent to a $25 \%$ response rate. Our prison guard sample accounts for $55 \%$ of the total staff complement of respondent prison staff. This return rate is more or less similar to that of Lourel et al. (2004) who used the same type of procedure.

\subsection{Data input and analysis}

The data was entered and analyzed using the StatView ${ }^{\odot}$ software version for Windows 5.0 (1992-1998). The statistical analysis of the data included variance analysis (ANOVA) to identify differences on the mean scores of the SCP-II between post-traumatic

\footnotetext{
${ }^{1}$ It should be noted that this variable "diagnostic level" is not a diagnosis.
} 
Table 2

EMS description.

\begin{tabular}{ll}
\hline Early maladaptive schemas & Description \\
\hline Abandonment/instability & $\begin{array}{l}\text { The perceived instability or unreliability of } \\
\text { significant others for emotional support and } \\
\text { connection. }\end{array}$ \\
The expectation that others will hurt, abuse, \\
humiliate, manipulate, or take advantage \\
intentionally. \\
The expectation that one's needs for \\
Emotional deprivation \\
nurturance, empathy, and protection will not \\
be met by others \\
The feeling that one is isolated from the world, \\
different from others, and/or not part of any \\
The belief that one is incapable of handling \\
day-to-day responsibilities competently and \\
independently \\
An exaggerated fear that an imminent and \\
unpreventable catastrophe (financial, natural, \\
medical, criminal) will strike at any moment. \\
Enerability to harm
\end{tabular}

stress symptoms groups and post-hoc analysis for exploring the directions of such relationships.

\section{Results}

\subsection{Prison Guard EMS re-enactment analysis}

ANOVA shows a significant difference in the prison guards' early maladaptive schemas: $\left.F_{(12 ;} 232\right)=104.348 ;=p<0.001 ; \square^{2}=0.31$ (Fig. 1).

Bonferroni/Dunn post-hoc test indicates that:

- the "Mistrust" EMS is significantly more activated than the other EMSs (systematically $p<0.0001$ );

- except for the "social isolation community" EMS, the "Dependence" EMS is significantly less activated than the other EMS (at least $p<0.006$ );

- two clusters of EMSs do not differentiate from each other. The first comprises "Self-Sacrifice-Abnegation", "Unrelenting Standards" and "Attachment" EMS and the second cluster contains "Enmeshment", "Emotional Deprivation", "Vulnerability To Harm" and finally "Abandonment".

\subsection{Post-traumatic stress "Diagnosis level" impact on EMS re-enactment analysis}

ANOVA indicates a significant EMS re-enactment differentiation according to the post-traumatic stress "Diagnosis Level" (no symptoms, ASD and PTSD): $F_{(12 ; 225)}=1,849 ; p=0.007 ; \square^{2}=0.13$.
Post-Traumatic Stress "Diagnosis Level" significantly impacts the intensity of EMS re-enactment (Fig. 2).

In addition, the Bonnferroni/Dunn post-hoc test shows that subjects with PTSD "diagnosis level" report a systematically more intense EMS re-enactment than subjects with no post-traumatic symptoms (for each case $p<0.016$ ). Subjects with ASD "diagnosis level" also report a higher EMS re-enactment than subjects with no post-traumatic symptoms (for each case $p<0.016$ ), except for "Mistrust", “Attachment" and "Unrelenting Standards" EMSs.

\section{Discussion}

\subsection{Prison: a mistrust re-enactment?}

The first report relates to the preeminence of the activation of the "mistrust" EMS in our sample. In Young's work (Schmidt et al., 1995; Young, 1990; Young et al., 2005), this refers to attitude characterized by an avoidance of relationships with others for fear of being betrayed or misled. The expectations that others will hurt, abuse, humiliate, manipulate, or take advantage of one intentionally. As we hypothesize, it seemed that prison and specifically inmates-to-guard relationships, differentiate EMS reenactment among prison guards.

Is it really surprising? Relationships between guards and inmates explain. in part, such a result (Chauvenet et al., 1994; Desombre, 2004). As a matter of fact, these interactions primarily originate from a hostile and asymmetrical environment (Blitz et al., 2008). The prison guards are responsible for keeping the inmates in prison but the inmates' first wish is to escape prison. Consequently, this core opposition between inmates and prison guards' objectives leads the guards to suspect that any of the inmates' behavior is an attempt to escape their control (Bond and Lee, 2005). These relationships could reinforce mistrust or suspicion against inmates. To our minds, the process appear to be located in a conscious part of the mind (cognition or thought such as "an inmate is an enemy") and behaviors ("I won't speak with inmates if it is not necessary").

What is more surprising is that these relationships and the prison atmosphere seemed to impact core psychological structures such as the EMS. EMSs are more unconscious than conscious thought or behavior. We would expect that prison guards "consciously" express the lack of trust they have for inmates. Mistrust EMS re-enactment mean that mistrust EMS is already enacted among prison guards.

How can we explain this result? We think that prison guards are specifically selected based on particular psychological criteria. They are employed in prison settings because of their ability to holdoff inmates (Boudoukha et al., 2003). The generalized environment of mistrust and the difficult implementation of communication helps tinge any social relations with negativism, and with the habitual "stand-offs" along with a deep-rooted cynicism (Ulmer, 1992). Moreover, this day-to-day work with inmates develops and reinforces conscious "mistrust" attitudes. That conscious set of behaviors and cognitions directed to inmates is progressively spread to others in a more unconscious way (Boudoukha et al. 2005).

We can metaphorically use the idea of contamination. This assimilation of prison world values acts as a re-enactment of an EMS. This is only possible if the existing EMS are still acceptable as valid representations of the world and others (Elwood et al., 2009).

\subsection{Vulnerability among prison guards}

Traumatic events are frequent in prison. Prison guards in our sample show a high level of post-traumatic stress symptoms. 


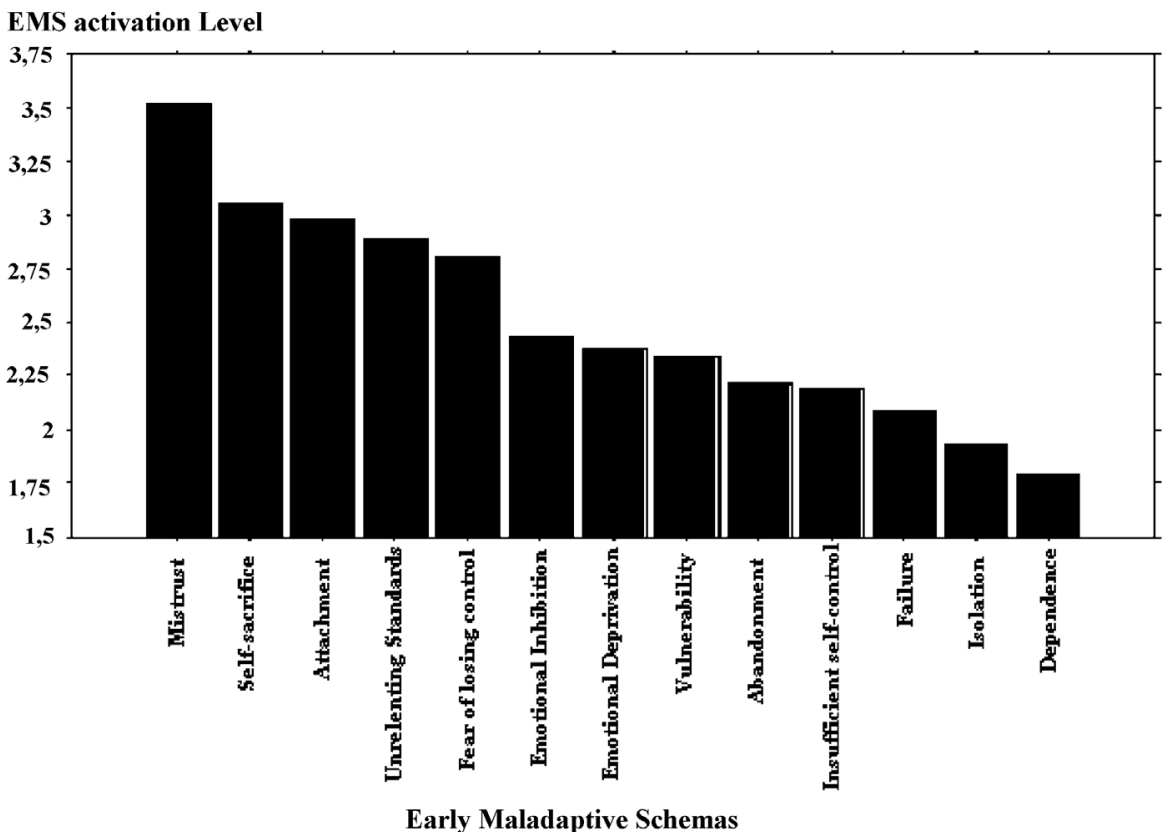

Fig. 1. Prison guard EMS activation level.

This result is interesting, because if traumatic event exposition is common among high-risk populations, prevalence of PTSD is less frequent (Nemeroff et al., 2006). It has been suggested that the ambivalent or negative attitudes displayed by certain sections of the US community after demobilization was a major factor in determining the high rates of PTSD in Vietnam veterans (Klein and Alexander, 2009). We think that suspicious and mistrustful guard-to-inmate attitudes act the same way. More specifically, guard-to-inmates' relationships spread throughout all kinds of relationships, leading to a lack of social support... The problem is that social support has a strong association with the development and progression of PTSD.

Moreover, results show a rise in the EMS re-enactment among the subjects with PTSD "diagnosis level” compared to the subjects with no post-traumatic symptoms as measured by IES-R. Schemas are said to be stable, hardly modifiable structures (Hautekeete, 1998; Rusinek et al., 2004). How can we conceptualize the impact of a traumatic event, leading to PTSS on an EMS?

Schema theoreticians such as Rothbart (1981) proposes the "Conversion model". It describes a "catastrophic", relatively abrupt change mechanism when the more usual schemas are confronted with a minimal number of highly improper and projecting critical cases. Traumatic event confrontation and PTSD development seem to explain this intense EMS re-enactment among prison guards. Nevertheless, it should be noted that with regard to the analysis of the EMS, we do not notice a completely different EMS organization whether subjects report no PTSD symptoms "diagnosis level" or ASD or PTSD “diagnosis level”. The "Diagnosis Level” produces

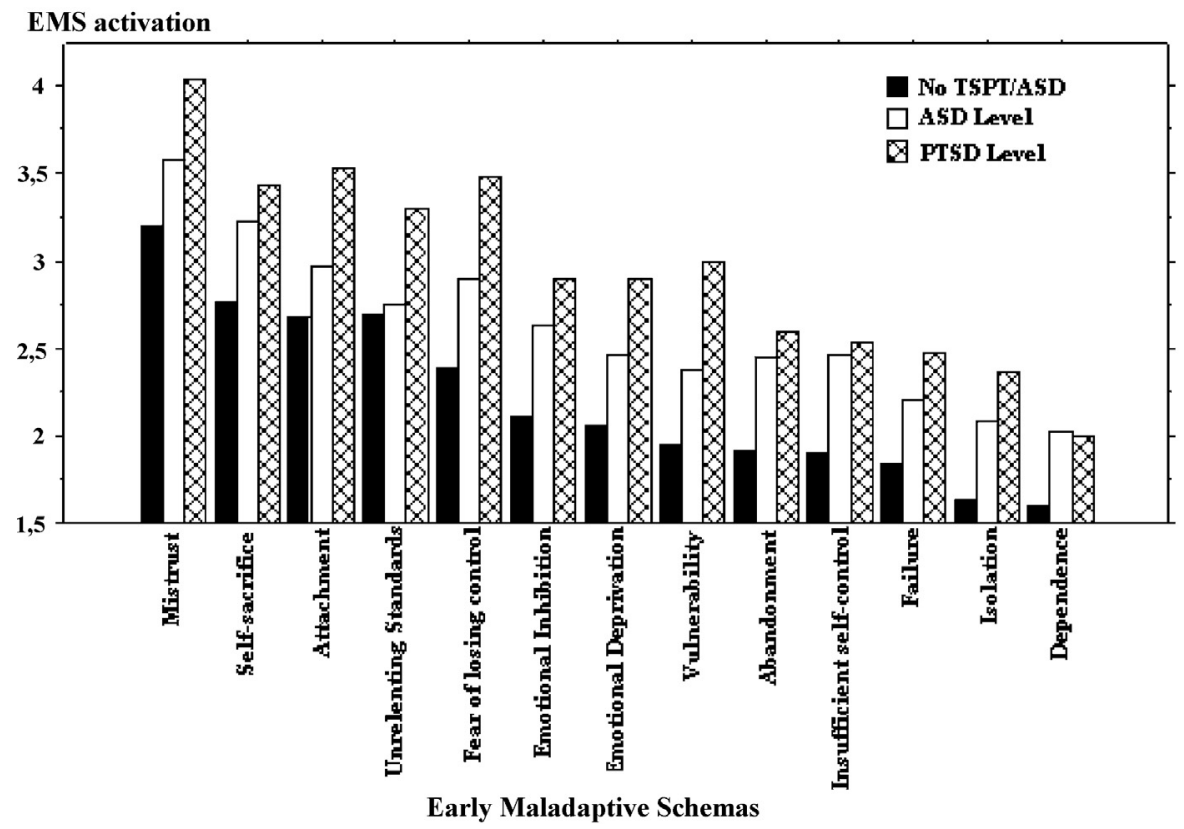

Fig. 2. EMS activation according to the post-traumatic stress "Diagnosis Level". 
an effect on schema activation, but the schema profile remains the same.

Foa and Rothbaum (1998) confirm Janoff-Bulman's hypothesis (1992) by proposing that the traumatic events will break the prior schemas and will lead to a constellation of intrusion and avoidance symptoms. They especially specify that such a conceptualization of PTSD appearance and development supposes that pre-traumatic schema contents are completely incompatible with what the event implies. The authors, however, emphasize the fact that not all the subjects have schemas inevitably opposed to or incompatible with the traumatic event (Foa et al., 1989). For many subjects, before the traumatic event, the world is already conceptualized as dangerous and unpredictable and/or they themselves see themselves as inefficient and worthless (Paunovic and Öst, 2001). Thus, Foa and Rothbaum (1998) propose that PTSD develops because the traumatic event will spark the vision of oneself as an extremely unskilled being, and of the world and others as extremely dangerous.

This postulate makes it possible for the authors to respond to the empirical evidence on PTSD vulnerability factors suggesting that pre-traumatic psychological and psychiatric disorders can be reasonably associated with negative visions of the world and oneself (Brewin et al., 2000; Ozer et al., 2003; Rothbaum et al., 1992). With regard to the pre-traumatic schemas, Foa and Rothbaum (1998) echo the thesis of Janoff-Bulman (1992) which relates to the various types of pre-traumatic schema-assumptions and which differentiates between the conceptualization of oneself and of the world. They highlight two registers of core schemas in post-traumatic consequences, in opposition to the three clusters of Janoff-Bulman (1992).

In the first register, the world and others are considered completely dangerous, and in the second, the individual sees his or herself as completely worthless. In addition, Foa and Rothbaum (1998) propose that this two-core set of schemas will inevitably interact. In fact, if others and the world are perceived as dangerous, it is not possible for the victim to be protected, and thus he or she feels worthless and becomes vulnerable and fragile when faced with events.

\section{Conclusion}

This research confirms (1) the traumatic impact of inmateon-guard attacks and (2) prison guard EMS re-enactment. EMS re-enactment such as "mistrust" could possibly explain French prison guards' complaints and psychological suffering. Senses of control and of justice are shattered by traumatic events and EMS re-enactment. Future research should investigate prison guards' beliefs in the "just world" (Hafer \& Bègue, 2005; Lerner, 1980), and locus of control (Przygodzki-Lionet et al., 2001).

Moreover, it appears that suspicious relationships isolate guards from any potential help, as personal relationships are avoided. Prison guard EMS re-enactment creates thoughts about the "malevolent aspect of the world and others", which reinforces mistrust and keeps the related EMS re-enacted. This type of explanation is validated, for example, by Bamber's work (Bamber and McMahon, 2008).

Finally, psychological help for prison guards is necessary, but not only following a traumatic event (Brillon, 2005). Psychotherapy should probably address prison guards' expressions of their feelings and focus more on changing their relationships with inmates to prevent psychological disorders (C.E.A. Wang et al., 2010).

\section{Disclosure of interest}

The authors declare that they have no conflicts of interest concerning this article.

\section{References}

APA, 2004. Practice guideline for the treatment of patients with Acute Stress Disorder and Posttraumatic Stress Disorder. American Psychiatric Association, Washington.

APA, 2003. DSM-IV-TR: manuel diagnostique et statistique des troubles mentaux $4^{\mathrm{e}}$ Ed. Masson, Paris (J. D. Guelfi, Trans.).

Bamber, M., McMahon, R., 2008. Danger-early maladaptive schemas at work! The role of early maladaptive schemas in career choice and the development of occupational stress in health workers. Clinical Psychology and Psychotherapy 15 (2) 96-112.

Blitz, C.L., Wolff, N., Shi, J., 2008. Physical victimization in prisons: the role of mental illness. International Journal of Law and Psychiatry 31 (5), 385-393.

Bond, G.D., Lee, A.Y., 2005. The darkest side of trust: validating the generalized communication suspicion scale with prison inmates. Personality and Individual Differences 38 (6), 1429-1438.

Boudoukha, A.H., Garay, D., Thomas, D., Tremlet, C., Maciejewski, S., 2003. Analyse psychopathologique des profils de surveillants de prison: selection des candidats lors des recrutements. Psychologues de la Direction Régionale des services pénitentiaires de Lille, pp. 4.

Boudoukha, A.H., Hautekèete, M., Georget, S., Lortioux, N., 2005. Influence du milieu de travail sur les schémas: exemple des surveillants de prison. Journal de Thérapie Comportementale et Cognitive 15 (Supplement 1), 15-115.

Brewer, W.F., Nakamura, G.V., 1984. The nature and function of schemas. In: Wyer, R.S., Srull, T.K. (Eds.), Handbook of social cognition, 1. Erlbaum, Hillsdale, New Jersey, pp. 119-160.

Brewin, C.R., Andrews, B., Valentine, J.D., 2000. Meta-analysis of risk factors for posttraumatic stress disorder in trauma-exposed adults. Journal of Consulting and Clinical Psychology 68 (5), 748-757.

Brillon, P., 2005. Comment aider les victimes souffrant de stress post-traumatique : guide à l'intention des thérapeutes. Les éditions Quebecor, Montréal.

Brunet, A., King, S., Weiss, D.S. (1998). Version française de l'Impact of Event Scale revised. Unpublished manuscript.

Brunet, A., St-Hilaire, A., Jehel, L., King, S., 2003. Validation of a French Version of the Impact of Event Scale-Revised. Can J Psychiatry 48 (1), 56-61.

Cason, D.R., Resick, P.A., Weaver, T.L., 2002. Schematic integration of traumatic events. Clinical Psychology Review 22, 131-153.

Chauvenet, A., Orlic, F., Benguigui, G., 1994. Le monde des surveillants de prison. Presse Universitaire de France, Paris.

DAP (2010). L’administration pénitentiaire en chiffres au $1^{\mathrm{er}}$ janvier 2010. Retrieved. From Ministère de la Justice.

DAP, 2009. Bilan Social. Direction de l'Administration Pénitentiaire, Paris.

Dalgleish, T., 2004. Cognitive approaches to posttraumatic stress disorder: the evolution of multirepresentational theorizing. Psychological Bulletin 130 (2), 228-260.

Desombre, C. (2004). Entitativité et stratégies identitaires dans des relations intergroupes asymétriques: une application en milieu carcéral. Unpublished Doctorat, Lille 3, Villeneuve d'Ascq.

Duburcq, A., Coulomb, S., Bonté, J., Marchand, C., Fagnani, F., Falissard, B., 2006 Étude épidémiologique sur la santé mentale des personnes détenues: Rapport final- Résultats des 3 phases de l'étude et synthèse (rapport). Ministère de la Santé (Direction Générale de la Santé) et Ministère de la Justice (Direction de l'Administration Pénitentiaire), Paris.

Elwood, L.S., Hahn, K.S., Olatunji, B.O., Williams, N.L., 2009. Cognitive vulnerabilities to the development of PTSD: a review of four vulnerabilities and the proposal of an integrative vulnerability model. Clinical Psychology Review 29 (1), 87 100.

Foa, E.B., Rothbaum, B.O., 1998. Treating the trauma of rape: cognitive therapy for PTSD. Guilford Press, New York.

Foa, E.B., Steketee, G., Rothbaum, B.O., 1989. Behavioral/cognitive conceptualizations of post-traumatic stress disorder. Behavior Therapy 20 (2), 155-176.

Hafer, C.L., Bègue, L., 2005. Experimental research on just world theory: problems, developments and future challenges. Psychological Bulletin 131, 128-167.

Hautekeete, M., 1998. Principes généraux des thérapies cognitives. In: SamuelLajeunesse, B., Mirabel-Sarron, C., Vera, L., Mehran, F., et al. (Eds.), Manuel de thérapie comportementale et cognitive. Dunod, Paris.

Hautekeete, M., Ameerudden, R., Eraldi-Gackière, D., Baert, R., Rusinek, S., 2006. L'évolution des schémas inadaptés durant et après une cure TCC chez des patients alcooliques qui rechutent ou ne rechutent pas : contribution à la théorie des schémas. Journal de Thérapie Comportementale et Cognitive 16 (1), 1626.

Hautekeete, M., Hautekeete-Sence, D., Rusinek, S., Graziani, P.L., Cordonnier, C., Humez, C. (2001). Le questionnaire de Schémas cognitifs forme adulte SCP II. Paper presented at the $29^{\mathrm{e}}$ Journée Scientifique de Thérapie comportementale et cognitive, Paris.

Janoff-Bulman, R., 1992. Shattered assumptions: towards a new psychology of trauma. Free Press, New York.

Janoff-Bulman, R., 2004. Posttraumatic growth: three explanatory models. Psychogical Inquiry 15 (1), 30-34.

Klein, S., Alexander, D.A., 2009. Epidemiology and presentation of post-traumatic disorders. Psychiatry 8 (8), 282-287.

Lerner, M.J., 1980. The belief in a just world: a fundamental delusion. Plenum Press, New York.

Lourel, M., Gana, K., Prud'homme, V., Cerclé, A., 2004. Le burn-out chez le personnel des Maisons d'arrêt: test du modèle "demande-contrôle " de Karasek. L'Encéphale 30 (6), 557-563. 
Magaletta, P.R., Patry, M.W., Wheat, B., Bates, J., 2008. Prison inmate characteristics and suicide attempt lethality: an exploratory study. Psychological Services 5 (4), 351-361.

Neisser, U., 1976. Cognition and reality. Freeman, San Francisco.

Nemeroff, C.B., Bremmer, D.J., Foa, E.B., Mayberg, H.S., North, C.S., Stein, M.B., 2006 Posttraumatic stress disorder: a state-of-the-science review. Journal of Pschiatric Reseach 40,1-21.

OMS, 1994. CIM-10. Classification internationale des troubles mentaux et du comportement : descriptions cliniques et directives pour le diagnostic. OMS, Genève.

Ozer, E.J., Best, S.R., Lipsey, T.L., Weiss, D.S., 2003. Predictors of posttraumatic stress disorder and symptoms in adults: a meta-Analysis. Psychological Bulletin 129 (1), 52-73.

Paunovic, N., Öst, L.-G., 2001. Cognitive-behavior therapy vs exposure therapy in the treatment of PTSD in refugees. Behaviour Research and Therapy 39 (10), 1183-1197.

Przygodzki-Lionet, N., Desrumaux-Zagrodnicki, P., Fachamps, M. (2001). Les victimes d'accident de la route: jugement de responsabilité et lieu de contrôle en relation avec l'anxiété. Paris: $5^{\mathrm{e}}$ colloque de Psychologie Sociale Appliquée.

Przygodzki-Lionet, N., Noël, Y., 2004. Individu dangereux et situations dangereuses: les représentations sociales de la dangerosité chez les citoyens, les magistrats et les surveillants de prison. Psychologie Française 49 (4), 409424.

Rothbart, M., 1981. Memory processes and social beliefs. In: Halmilton, D. (Ed.), Cognitive processes and group behavior. Erlbaum, Hilldale, NJ.

Rothbaum, B.O., Foa, E.B., Riggs, D.S., Walsh, W., 1992. A prospective examination of post-traumatic stress disorder in rape victims. Journal of Traumatic Stress 5 (3), $455-475$.

Rummelhart, D., 1975. Notes on a schemas for stories. In: Bobrow, D.G., Collins, A.M. (Eds.), Representation and understanding: studies in cognitive science. Academic Press, New York, pp. 211-236.
Rusinek, S., 2006. Soigner les schémas de pensée : une approche de la restructuration cognitive. Dunod, Paris.

Rusinek, S., Graziani, P., Servant, D., Deregnaucourt, I., 2004. Thérapie cognitive et schémas cognitifs : un aspect du paradoxe. Revue Européenne de Psychologie Appliquée 54, 173-177.

Schmidt, N., Joiner Jr., T.E., Young, J.E., Telch, M.J., 1995. The Schema Questionnaire: investigation of psychometric properties and the hierarchical structure of a measure of maladaptive schemas. Cognitive Therapy and Research 19 (3), 295-321.

Sorensen, J.R., Cunningham, M.D., Vigen, M.P., Woods, S.O., 2011. Serious assaults on prison staff: a descriptive analysis. Journal of Criminal Justice 39 (2), 143-150.

Ulmer, J.T., 1992. Occupational socialization and cynicism toward prison administration. Social Science Journal 29 (4), 423-444.

Vaiva, G., Brunet, A., Lebigot, F., Boss, V., Ducrocq, F., Devos, P., et al., 2003. Fright (Effroi) and other peritraumatic responses after a serious motor vehicle accident: prospective influence on acute PTSD development. The Canadian Journal of Psychiatry 48 (6), 395-401.

Wang, C.E.A., Halvorsen, M., Eisemann, M., Waterloo, K., 2010. Stability of dysfunctional attitudes and early maladaptive schemas: a 9-year follow-up study of clinically depressed subjects. Journal of Behavior Therapy and Experimental Psychiatry 41 (4), 389-396.

Wang, L., Zhang, J., Shi, Z., Zhou, M., Huang, D., Liu, P., 2011. Confirmatory factor analysis of posttraumatic stress symptoms assessed by the Impact of Event Scale-Revised in Chinese earthquake victims: examining factor structure and its stability across sex. Journal of Anxiety Disorders 25 (3), 369-375.

Young, J.E., 1990. Cognitive therapy for personality disorders: a schema-focused approach. Professsional ressource Press, Sarasota.

Young, J.E., Klosko, J.S., 1993. Je réinvente ma vie. Les éditions de l'homme, Montréal.

Young, J.E., Klosko, J.S., Weishaar, M.E., 2005. La thérapie des schémas: approche cognitive des troubles de la personnalité. De Boeck Université, Bruxelles. 